\title{
COLLECTIVE BARGAINING BY SUPERVISORY EMPLOYEES UNDER THE WAGNER ACT
}

In the current and heated dispute between management and labor over the right of supervisory employees ${ }^{\text {x }}$ to bargain collectively under the Wagner Act, ${ }^{2}$ the National Labor Relations Board has found itself thrust into the difficult role of arbitrator. The fact that supervisory employees do not fit neatly into either the labor pigeonhole or the management pigeonhole-such dichotomy being implicit in the Wagner Act - has been a constant source of difficulty to the Board. The continued silence on the part of Congress, the lack of any judicial determination of the bargaining rights of supervisory employees under the act, and the divergent views within the Board itself have contributed to the uncertainty surrounding the problem. The current position taken by the three-man Board, that supervisory employees may constitute appropriate bargaining units under the act, rests upon a slim two-to-one majority. The same majority has held that under the Wagner Act the right to bargain is not limited to foremen in the mass production industries who function as "traffic cops" but may be extended to supervisory groups higher up the employment ladder. ${ }^{3}$ The more important question as to the appropriateness of affiliation between supervisory employees and production workers in the same unions has been decided affirmatively when the respective employees are grouped in separate bargaining units. 4

I At the outset, difficulties are encountered in attempting to define categorically the "supervisory employee" or "foreman" as distinguished from the production or maintenance worker on the one hand and the employer on the other. There are considerable variation and overlapping of function from industry to industry and from plant to plant, but certain general criteria particularly manifest in the mass production industries can be noted to provide a working definition. ( $x$ ) Foremen do little or no mechanical work, their primary task being to supervise the work of others. (2) They recommend promotions, transfers, layoffs, disciplinary measures, but they do not have final authority to effectuate their recommendations. (3) They are executors of plans, policies, and production schedules handed down by higher management; they have little or nothing to do with policy making. See National War Labor Board, Report and Findings of the Foremen's Panel I4 (r945), hereafter referred to as "Slichter Report."

"The Board has found, as have the courts, that the definitions of 'employer' and 'employee' contained in the Act are not mutually exclusive; that a foreman, for example, is an 'employer' when he acts in the interest of his employee, but he is an 'employee' when he acts in his own interest, as when he seeks to better the terms and conditions of his employment." Matter of Jones \& Laughlin Steel Corp., 66 N.L.R.B. No. 5 I, I 7 Lab. Rel. Rep. 97 I (1946), and cases cited.

2 National Labor Relations Act, 49 Stat. 449 (I935), 29 U.S.C.A. \$ I5I (I942). There is no mention of supervisory employees in the act as there is in the Railway Labor Act in which (since I934) subordinate officials are expressly termed "employees." 54 Stat. 898 (I940), 45 U.S.C.A. \& I5I (1943).

${ }_{3}$ Matter of Federal-Mogul Corp., 66 N.L.R.B. No. 70, 17 Lab. Rel. Rep. 975 (1946); Matter of Jones \& Laughlin Steel Corp., 66 N.L.R.B. No. 5I, I7 Lab. Rel. Rep. 97I (1946); Matter of L. A. Young Spring \& Wire Corp., 65 N.L.R.B. No. 59, I7 Lab. Rel. Rep. 687 (1946); Matter of B. F. Goodrich Co., 65 N.L.R.B. No. 58, I7 Lab. Rel. Rep. 692 (1946).

4 Matter of Jones \& Laughlin Steel Corp., 66 N.L.R.B. No. 5I, 17 Lab. Rel. Rep. 971 (1946); cf. Matter of Industrial Collieries Corp., 65 N.L.R.B. No. I I8, I 7 Lab. Rel. Rep. 785 (I946). 
The House of Representatives passed the Case Bill, later rejected by the Senate, which would have denied supervisory employees the protection of the Wagner Act altogether. ${ }^{5}$ The Chrysler Corporation, in its new contract with the United Automobile Workers of America, insisted upon and got an acknowledgment by the union that supervisory employees were a part of management and a promise that the union would neither seek to organize foreman nor bargain for them. ${ }^{6}$ The Packard Motor Car Company and the Foremen's Association of America are seeking a United States Supreme Court adjudication of the status of foremen under the Wagner Act. 7 The coal mining operators are planning a court fight against the National Labor Relations Board's recent decision sanctioning affiliation. ${ }^{8}$ These developments underscore the great importance of the foreman issue in management and labor relations today.

At the time when the Wagner Act was passed there were no significant organizations of supervisory employees. In the few industries where they were organized, notably in the building and printing trades, they usually belonged to the same unions as the production workers but were precluded in one way or another from exercising much influence in union affairs. 9 In the maritime and railroad industries and in the Postal Service, some significant unions composed of only supervisory employees had developed, but prior to the Wagner Act they had raised no special problems. ${ }^{10}$

The basic impulses toward large scale unionization of foremen were of comparatively recent origin and inextricably linked with the development of massproduction industries and the coming of age of the industrial unions. At one time the foreman exercised considerable discretionary power and was vested with many of the prerogatives of management. He hired, fired, had considerable

5 H. Res. 5262, 79 th Cong. 2d Sess. (February 7, 1946); rejected by Senate Committee on Education and Labor, which substituted the Federal Mediation Bill of 1946 , 17 Lab. Rel. Rep. IOI 2 (1946). Section I2 (b) of the Case Bill provided that, "Hereafter, no supervisory employee shall have the status of an 'employee' for the purposes of Sections 7,8 , and 9 of the National Labor Relations Act.” i7 Lab. Rel. Rep. 748 (1946). An Alabama statute (Ala. Gen'l Acts, 1943 Session, No. 298, \& 16 [r943]) makes it unlawful for any rank and file labor organization to accept any executive, professional, or supervisory employee as a member; and it is made unlawful for such persons to obtain membership in such an organization. Dodd, Some State Legislatures Go to War-on Unions, 29 Iowa L. Rev. 148, I68 (I944).

${ }^{6}$ See 17 Lab. Rel. Rep. 775 (1946). It is interesting to note that in I939 the UAW made the same agreement with the Chrysler Corporation, thus terminating an attempt by the CIO to organize foremen in the automotive industry. 5 Lab. Rel. Rep. 355 (1939).

7 The Packard Motor Company has appealed to the Circuit Court of Appeals for the Sixth Circuit from the decision of the Board in Matter of Packard Motor Car Co., 64 N.L.R.B. No. 204, 17 Lab. Rel. Rep. 506 (I945), and 6r N.L.R.B. 4 (I945).

${ }^{8}$ I7 Lab. Rel Rep. Ior I (I946); Chicago Sun, p. 3, col. 6 (March 8, I946).

9 Slichter Report, op. cit. supra, note I, at 49 ; U.S. Dept. of Labor, Union Membership and Collective Bargaining by Foremen (1943); American Management Association, Research Report No. 6, The Unionization of Foremen (1945); Northrup, The Foremen's Association of America, 23 Harv. Bus. Rev. 187 (1945); The Foreman Abdicates, 32 Fortune, No. 3, at 150 (Sept., 1945).

20 See note 9, supra. 
voice in the setting of production schedules and wage rates, imposed discipline, and enjoyed a substantial wage differential over the rank and file workers. With increasing specialization and centralization of control, the foreman's status deteriorated. The industrial engineer's slide rule supplanted the foreman's rule of thumb, and the centralized personnel manager took over the hiring and firing functions. With the growth of industrial unions the foreman's disciplinary function was circumscribed by grievance procedures invoked by the shop steward and taken to top management as a matter of course. Foremen's wages lagged behind the increases obtained by the rank and file through their unions, and foremen's insecurity of tenure was pointed up by the production workers' acquisition of seniority rights and right of appeal against dismissal without cause. The war accentuated and accelerated these developments. Production workers received substantial wage increases, due, primarily, to time and a half and double time provisions which the average foreman on a flat salary could not get because of the wage-stabilization program. Then, too, during the war, there was a tremendous increase in the number of foremen, all facing the probability of demotion or layoff with attendant loss of seniority at the war's end. The foreman's loss of status and increasing insecurity resulting from these developments made recourse to organization for collective bargaining purposes inevitable."I By I942, powerful supervisory-employee unions had sprung up in industries which had had no previous history of this phenomenon. ${ }^{\mathrm{x}}$

In I940 the Mine Officials' Union of America, an independent supervisors' union, was organized in the coal mining industry. The union enjoyed only mediocre success until its certification as an appropriate bargaining unit by the NLRB in I942. Immediately thereafter the union affiliated with John L. Lewis' United Mine Workers, changed its name to the United Clerical, Technical and Supervisory Employees of America, (UCTSE), division of District 50, and by I943 claimed a membership of some 14,000 persons. ${ }^{\mathrm{x}}$ The Foremen's

" See Daykin, The Status of Supervisory Employees under the National Labor Relations Act, 29 Iowa L. Rev. 297, 313 (1944).

12 For a detailed account see Matter of Packard Motor Car Co., 6r N.L.R.B. 4, 9 ( (r945), Matter of Maryland Drydock Co., 49 N.L.R.B. 733, 742 (I943); Slichter Report, op. cit. supra; note 1 , at 38 ; Northrup, op. cit. supra, note 9 . For a somewhat emotional treatment of the foreman's problems see Roethlisberger, The Foreman: Master and Victim of Double Talk, 23 Harv. Bus. Rev. 283 (1945). See also Hearings before the Committee on Military Affairs, House of Representatives, 78th Cong., Ist Sess., on H. R. 2239, H. R. I742, H. R. I728, and H. R. 992, Full Utilization of Manpower (r943), referred to hereafter as Hearings on the Smith Bill.

${ }_{33}$ "At the time of the original representations by the MOU, the UMWA constitution barred supervisors from membership. In October, I942, however, the UMWA constitution was amended by the addition of the following clause: 'The International Executive Board may, in its discretion, provide rules and regulations upon which supervisory and other employees may be admitted to membership.' In February, I943, the UMWA's International Executive Board, acting on a petition of the MOU and pursuant to the amended constitution, passed a resolution admitting members of the MOU to individual membership in the UMWA as of April r, I943, the date on which the outstanding contracts between the UMWA and the coal operators expired. The MOU thereupon ceased to exist.

"Originally, the International Executive Board of the UMWA planned to have the super- 
Association of America (FAA), composed exclusively of supervisory employees, was organized in I94I in the automobile industry. The FAA had phenomenal success, branched out into other industries, and in I945 had more than 32,000 members. ${ }^{74}$ Other unions of supervisory employees have been organized, particularly during the war, ${ }^{15}$ but the FAA has been the most articulate and determined group seeking a seat at the bargaining table. The strength which these organizations had attained was illustrated by the serious strikes of the FAA $^{16}$ and the UCTSE ${ }^{77}$ in the automobile and coal mining industries subsequent to the Board's decision in Matter of Maryland Drydock Co. ${ }^{18}$ placing supervisory employees outside the protection of the Wagner Act. ${ }^{\text {I9 }}$

The issues raised by the rapid growth of supervisory employees' unions seeking collective bargaining rights have been unique and explosive. Besides employers' normal reluctance to any extension of collective bargaining privileges, ${ }^{20}$

visors admitted as members of rank and file locals. However, in October, I943, the Executive Board wisely altered this plan. It created the UCTSE to organize supervisors, clerical and technical employees in the coal mining industry." Matter of Jones \& Laughlin Steel Corp., 66 N.L.R.B. No. 5 I (1946), page Io of memorandum of decision; National War Labor Board, Report and Findings of the Panel on Coal Supervisors 7 (1945), hereafter referred to as Coal Panel Report; Report, American Management Association, op. cit. supra, note 9, at 17 .

${ }^{14}$ Slichter Report, op. cit. supra, note I, at 2I; Collective Bargaining Seminar, No. 8, Foremen's Unions, Univ. Chi. Indust. Relations Center (1945); Report, American Management Association, op. cit. supra, note 9, at 8; The Foreman Abdicates, 32 Fortune, No. 3, at 150 (Sept., r945); Northrup, op. cit. supra, note 9.

15 In 1939, the United Automobile Workers of America began organizing foremen in the Detroit area but this development was short-lived when the automobile manufacturers took a strong adverse stand; the UAW, more concerned with its rank and file members, withdrew their support. Slichter Report, op. cit. supra, note I, at 2r. The CIO has organized supervisors in the shipbuilding industries, but only on the very lowest levels. The Mechanics Educational Society of America with 50,000 members, mainly in Michigan and Ohio, also began organizing foremen in separate locals. In addition, independent foremen's unions sprung up in individual plants which were engaged in war production. Report, American Management Association, op. cit. supra, note 9, at 20.

${ }^{16}$ The FAA engaged in a twenty-day stoppage of production in seventeen Detroit war plants in April and May, 1944, in an all-out bid for company recognition. Report, American Management Association, op. cit. supra, note 9, at 13.

${ }_{17}$ The strikes called by the UCTSE in July and August, I944, seriously affected mining in ". . . . upwards of ro mines owned by 69 companies in Pennsylvania, West Virginia, Kentucky and Alabama." Coal Panel Report, op. cit. supra, note 13, at I.

${ }^{18} 49$ N.L.R.B. 733 (I943).

39 Panels in each instance were appointed by the National War Labor Board to determine the grievances of the foremen, and failure by the foremen to gain recognition and get colective bargaining agreements with management was found to be the underlying complaintthis despite the fact that the issue was outside the jurisdiction of the panels.

${ }^{20}$ "I also believe that there should be added to the Four Freedoms we speak so much about, another freedom-the Freedom of Opportunity, or perhaps it should be called the Freedom of Individual Initiative.

"If the foreman is willing to trade his faith in his ability to get ahead on the basis of his own individual initiative for the lulling influence or the creeping paralysis of mass security on a lower standard of living, he does not have the stuff that it takes." Coen, The Foreman as a Part of Management, 66 Mechanical Engineering 249, 250 (April, I944). (Mr. Coen is Director of Labor Relations, General Motors Corporation.) 
they have more cogent objections to bargaining with supervisory employees. They believe that this development would represent a fundamental encroachment upon management's prerogatives and would deprive them of considerable control over their business. ${ }^{2 x}$ It is further argued that the productive efficiency of industrial plants would be seriously impaired, output would decline and overall production costs would soar. ${ }^{22}$ These beliefs are predicated upon several basic assumptions. Management's main contention is that supervisory employees are an integral part of management who if unionized would have their loyalties divided and would, in effect, "be sitting on both sides of the bargaining table." Further, if employees on the lower supervisory levels are permitted to engage in collective bargaining, it is argued that there is no limitation as to how high up the managerial ladder the right will be extended, to the growing impairment of the managerial function. ${ }^{23}$ Most important of all, management asserts that even granting that collective bargaining by supervisory employees completely independent of the rank and file unions might conceivably work out, the supervisory employees, if not absorbed outright by the more powerful production workers' organizations, are more or less vulnerable to their domination and under these conditions management cannot hope to function effectively. ${ }^{24}$

Confronted with this conflict of interests, the Board found its task made more difficult by the complete lack of any legislative guide other than the broad expressions of policy in the Wagner Act. ${ }^{25}$ Not only was there no express provision for supervisory employees, but there were no references to supervisory employ-

${ }^{2 x}$ See the testimony of management representatives in the Hearings on the Smith Bill. op. cit. supra, note I2. Charles E. Wilson, president of General Motors Corporation stated:

"Apparently in industry now we are afraid that if the foremen join workmen's unions, the workmen will take the plants over. I think that is a reasonably anticipated event." Ibid., at 76.

$=2$ Ibid., at 9 r.

23 See note 34, infra.

${ }_{24}$ "When foremen are conceded to have the right to organize they also have the right to choose their representatives and affiliations. The three large national unions, the American Federation of Labor, the Congress of Industrial Organizations, and District No. 50 of the United Mine Workers, will by the nature of the case, actively compete for the affiliation of these foremen's unions. When the foremen's union in a particular plant affiliates with a national labor organization such as the American Federation of Labor while the union of workmen they supervise is affiliated with a rival organization such as the Congress of Industrial Organization [sic] or District No. $5^{\circ}$ of the United Mine Workers, it is easy to visualize the complete break-down of authority and internal plant discipline that will result. Thus a law which was ostensibly passed by Congress to promote industrial peace will have produced a condition of industrial anarchy." Hearings on the Smith Bill, op. cit. supra, note 12, at 64 .

${ }_{25}$ "It is hereby declared to be the policy of the United States to eliminate the causes of cer-" tain substantial obstructions to the free flow of commerce and to mitigate and eliminate these obstructions when they have occurred by encouraging the practice and procedure of collective bargaining and by protecting the exercise by workers of full freedom of association, selforganization, and designation of representatives of their own choosing, for the purpose of negotiating the terms and conditions of their employment or other mutual aid or protection." National Labor Relations Act \& I, 49 Stat. 449 (I935), 29 U.S.C.A. \$ I5I (I942). 
ees in the Congressional hearings or debates on the act. In short, there was no evidence that Congress envisaged the problem, much less manifested its intent with regard to it. ${ }^{26}$ Furthermore, the previous experience of the Board with supervisory employees was of no help in its approach to these issues. Previous to the growth of foremen's unions, the thrust of the Board's decisions in cases involving supervisory employees had been to safeguard the rights of the rank and file, under section 8 of the act, against undue and illegal influence by representatives of management, i.e., supervisory employees. ${ }^{27}$

In view of this background it is not surprising that the Board's decisions have been neither consistent nor unanimous. Today the majority holds that supervisory employees cannot be denied the bargaining privileges of the Wagner Act. To arrive at this position the Board has reversed itself twice within the past four years. In this conflict between the two divergent views, Ex-chairman Millis and Member Reilly have been the chief antagonists.

The first case to come before the Board specifically raising the question as to whether supervisory employees came under the act was in 1942 in Matter of Union Collieries Coal Co. ${ }^{28}$ when a local of the then independent Mine Officials Union of America sought certification as an appropriate bargaining unit. Chairman Millis and Member Leiserson took the position that supervisory employees were employees within the broad definition of section $2(3)$ of the act ${ }^{29}$ and so entitled to certification. Member Reilly dissented. ${ }^{30}$ In Matter of Godchaux Sugars, Inc., ${ }^{3 x}$ decided a month later, the Board first passed on a case of affiliation and certified a CIO local composed of working and non-working foremen.

The essential issue presented here is whether supervisory personnel are to be denied statutory protection of those rights [i.e. to organize and bargain collectively]

${ }^{26}$ "There is nothing, however, in the committee reports or in the debates in the House and Senate which would indicate that this specific problem [i.e., supervisory employees] was ever considered by the Congress." Matter of Maryland Drydock Co., 49 N.L.R.B. 733 , 738 (1943).

${ }^{27}$ See N.L.R.B. v. Link-Belt Co., 3II U.S. 584 (I94I); H. J. Heinz Co. v. N.L.R.B., $3^{\text {II U.S. }} 5^{\mathrm{I} 4}$ (I94I), upholding the Board's findings of an unfair labor practice where supervisory employees had induced production workers to sign up with the company union. However, supervisory employees were also held to be "employees" under the act and entitled to the protection provided in section 8 of the act against discrimination and unfair labor practices, N.L.R.B. v. Skinner \& Kennedy Stationery Co., II3 F. 2d 667, 67I (C.C.A. 8th, I940). For an exhaustive analysis of this phase of the problem of supervisory employees, see Daykin, op. cit. supra, note II.

${ }^{28} 44$ N.L.R.B. 165 (I942).

29 "The term 'employee' shall include any employee ... . "except farm workers and domestic help. National Labor Relations Act $\& 2$ (3), 49 Stat. $449,45^{\circ}$ ( $x_{935}$ ), 29 U.S.C.A. $\& 5^{2}$ (3) (1942) (italics added).

${ }^{30}$ In every subsequent case dealing with the appropriateness of units of supervisory employees for collective bargaining under the Wagner Act, Member Reilly has held that they are not appropriate.

${ }^{32} 44$ N.L.R.B. 874 (I942). 
merely because they have selected a representative which is an affliate of the same parent organization as is the spokesman for subordinate employees. We think not.

The right given to employees to select representatives of their own choosing "is a fundamental right. . . .."32

In I943, Member Leiserson left the Board and new Member Houston joined with Reilly in Matter of Maryland Drydock Co.33 to overthrow the two previous decisions. This case dealt with a group of minor supervisory employees who asked either to be incorporated into the existing CIO unit of non-supervisory employees, or to be certified as a separate CIO local. Here Chairman Millis and Member Reilly first spelled out in detail their divergent views as to the applicability of the Wagner Act to supervisory employees. Member Reilly argued that the language of section $2(3)$ was so broad that in the absence of any evidence of Congressional intent from outside sources, Congress obviously could not have meant to include all the persons who could be included within the definition of "employee." Thus the question of whether or not to certify a particular unit as appropriate for collective bargaining was one reserved to the administrative discretion of the Board under section $9(\mathrm{~b})$, and therefore supervisory employees could be denied certification. His policy arguments against certification were substantially the same as those advanced by management. ${ }^{34}$

He emphasized that not only would supervisory employees affiliated with a rank and file union be inappropriate but also independent foremen's unions would be denied certification:

For, although supervisors may nominally constitute a separate bargaining unit, it is clear that they may-as they did in the case at bar-affiliate with and designate as their representative the same union which represents their subordinates. ${ }^{35}$

Chairman Millis, in his dissent, elaborated the position upon which the previous foremen cases hàd been decided. He branded Member Reilly's legal argument as an unauthorized limitation on the Wagner $\mathrm{Act}^{36}$ and proceeded to question the validity of the majority's policy arguments. He concluded that supervisors in mass production are a group of employees whose right to organize and bargain collectively under the protection of the Act should no more be denied than that of any other group of employees. Bargaining through separate units, with their own organizations, or in separate local unions affiliated with the internationals to which the rank and file are affiliated, or even through the same union as represents the rank and

$$
32 \text { Tbid., at } 877 . \quad{ }^{33} 49 \text { N.L.R.B. } 733 \text { (1943). }
$$

34 ". . . in the present stage of industrial administration and employee self-organization, the establishment of bargaining units composed of supervisors exercising substantial managerial authority will impede the processes of collective bargaining, disrupt established managerial and production techniques, and militate against effectuation of the policies of the Act." Ibid., at 74I.

35 Tbid., at 74 I.

${ }^{36}$ "Manifestly to engraft upon the Act an amendment which denies to a substantial segment of employees as a class the protection vouchsafed therein to all 'employees' is not within the permissible bounds of administrative discretion. It is administrative legislation." Ibid., at 743 . 
file, no problems should arise which are not susceptible of solution as indicated above. The policy established by the majority attempts to prevent difficulties from arising through foremen's organization, by denying foremen's organization the protection of the Act. This is a policy of negation, which does nothing towards a constructive solution of the real problems of the foremen. 37

For two years after the Maryland Drydock decision all attempts by foremen to obtain certification by the Board in independent as well as affiliated unions were unsuccessful, ${ }^{8}$ although in Matter of Soss Manufacturing Co. ${ }^{39}$ the Board unanimously held that foremen came under the Wagner Act to the extent of being protected from managerial discrimination because of union activities. The Board also continued to certify unions of supervisory employees in those industries in which there had been a history of bargaining by foremen antedating the Wagner Act.40 Then, in March, I945, in Matter of Packard Motor Co.,47 dealing with a unit of the Foremen's Association of America, Member Houston changed his mind and sided with Chairman Millis to overthrow the Maryland Drydock ruling to the extent of holding that independent foremen's unions were appropriate bargaining units under the act.

Shortly after this case was decided, Chairman Millis resigned and was succeeded by Paul M. Herzog, former chairman of the New York State Labor Relations Board. ${ }^{2 z}$ In subsequent proceedings, when the Packard Motor Company failed to comply with the Board's order, Chairman Herzog followed the line taken in the earlier Packard decision, expressly reserving, however, the question of affiliation. ${ }^{43}$ In Malter of L. A. Young Spring $\mathcal{O}^{\circ}$ Wire Corp..${ }^{44}$ decided January 8, 1946, and dealing with a local of the Foremen's Association of America, Chairman Herzog elaborated on the Packard ruling by stating that the Board not only should not, as a matter of policy, deny foremen the collective bargaining benefits of the Wagner Act, but that the Board could not, as a matter of law, exclude them. Again, the problem of affiliation was expressly reserved.

37 Tbid., at 749 .

${ }^{38}$ Matter of General Motors Corp., 5I N.L.R.B. 457 (1943); Matter of Murray Corp. of America, 5I N.L.R.B. 94 (1943); Matter of Boeing Aircraft Co., 5I N.L.R.B. 67 (1943.)

${ }^{39} 56$ N.L.R.B. 348 (I944).

40 Matter of Ohio Barge Line, Inc., 59 N.L.R.B. 154 (1944); Matter of Jones \& Laughlin Steel Corp., 54 N.L.R.B. 679 (1944); Matter of W. F. Hall Printing Co., 5r N.L.R.B. 640 (1943).

4 6I N.L.R.B. 4 (I945).

12 The New York State Labor Relations Board never followed the lead of the N.L.R.B. in Matter of Maryland Drydock Co., but continued to hold that there was no bar to certification of supervisory employees as a class. Matter of RKO Service Corp., 7 N.Y.S.L.R.B. I75 (I944); Matter of Allegheny Ludlum Steep Corp., 7 N.Y.S.L.R.B. I03 (I944); Matter of Bee Line Inc., 6 N.Y.S.L.R.B. 686 (I943). The Pennsylvania State Labor Relations Board has followed the Maryland Drydock case. Matter of Pittsburgh Railway Co., 42 P.S.L.R.B. 143 (1943).

43 Packard Motor Car Co., 64 N.L.R.B. No. 204, 17 Lab. Rel. Rep. 506 (1945).

4465 N.L.R.B. No. 59, I7 Lab. Rel. Rep. 687 (1946). 
Then, in Matter of Jones \& Laughlin Steel Corp.,45 decided March 7, I946, the affiliation question came squarely before the Board when the United Clerical, Technical and Supervisory Employees sought certification as an appropriate bargaining agent for a unit of supervisory employees in one of the steel company's captive coal mines. The majority of the Board, adverting to its line of reasoning in the early Godchaux case, held that

the Act contains no specific language empowering the Board to disqualify a freely chosen, legitimate labor organization, not company-dominated, as the collective bargaining representative of persons already found to be "employees" within the Act. . . . . Once the Board determines that certain employees are properly grouped, it has discharged its function under this section [gb]. As the statute is now written we find no authority to step beyond this point and, because of some concern as to what might be best for industry or even for employees, declare that certain employees may not express their uninhibited choice because the petitioner happens to be an affliate of the labor organization which represents a company's rank and file employees..$^{46}$

In reversing the Maryland Drydock decision the Board has returned to the only sound legal position possible under the express language of the act. Member Reilly has never denied that foremen and other supervisors were employees under section $2(3)^{47}$ of the act. His reliance upon section $9(b)$ as giving the Board the authority to deny certification to units of supervisory employees is untenable. Section 9 (b) states:

The Board shall decide in each case whether, in order to insure to employees the full benefit of their right to self-organization and to collective bargaining, and otherwise to effectuate the policies of this Act, the unit appropriate for the purposes of collective bargaining shall be the employer unit, craft unit, plant unit, or subdivision thereof. $4^{8}$

As the present majority has repeatedly indicated, "This is language of classifcation and not of exclusion. It authorizes the Board to select between alternatives as to which type of unit will best effectuate the policies of the Act; it gives us no license to hold that some persons who are 'employees' belong in no unit whatsoever." 49

Even were Member Reilly's construction of section 9 (b) valid, the certification of units of supervisory employees would be the only sound approach which could be taken by the Board. The findings of the War Labor Board panels in the foremen's disputes ${ }^{50}$ and the testimony of the foremen in the hearings on the Smith Bill in $1943^{5 I}$ afforded ample evidence that the foreman, at least in the

4566 N.L.R.B. No. 5r, I7 Lab. Rel. Rep. 97 x (1946).

${ }^{46} \mathrm{Ibid}$., at 972. In Matter of Industrial Collieries Corp., 65 N.L.R.B. No. I 18 , 77 Lab. Rel. Rep. 785 (1946) decided one month earlier, the Board certified a union local of non-supervisory employees, clerks in the accounting department, as an appropriate bargaining unit even though it was affliated with the UCTSE which organizes supervisory employees. While not squarely in point, the decision forecast the Board's subsequent sanctioning of affiliation.

47 Note 29, supra.

${ }^{4}$ National Labor Relations Act $\S 9$ (b), 49 Stat. 453 (I935), 29 U.S.C.A. $\S$ I59(b) (I942).

49 Matter of Maryland Drydock Co., 49 N.L.R.B. 733, 743 (1943).

so Note I9, supra.

5I Hearings on the Smith Bill, op. cit. supra, note 12. 
coal and mass production industries, identifies himself more closely with labor than with management. If he is not given the opportunity extended to other employees to obtain the benefits of collective bargaining by means of the Wagner Act, he will-as the events following the Maryland decision illustrated -resort to strikes and other weapons of industrial strife. Since it is the express policy of the Wagner Act "....to eliminate the causes [i.e., labor disputes] of certain substantial obstruction to the free flow of commerce .... by encouraging the practice and procedure of collective bargaining....,",52 the inclusion of supervisory employees' unions under the act was imperative.

To the argument that Congress did not provide for this problem and therefore an administrative board should not assume the responsibility of deciding what is essentially a matter for legislative determination, Chairman Herzog has given the only possible answer:

In the absence of any court decision, .... Congressional mandate, or other declaration of national policy to the contrary .... and in the further absence of proof that collective bargaining by supervisory employees has failed where it has been attempted, it is better that a Board dedicated to encouraging the bargaining process move forward, not backward, and continue to put a premium on the conference table rather than on harsh arbitrament of industrial war. ${ }^{53}$

Once the Board had determined that supervisory employees came within the operation of the act, the subsequent decision that affliation would be no bar to certification was essential. As Member Reilly has indicated, foremen's groups can remain absolutely independent only at the sufference of the productionworkers unions, which today usually have the power to break any strike of supervisory employees that they do not wish to support.54 Not only will the foremen find it necessary to enter into mutual pacts and agreements with the rank and file unions as they have done, ss but also the situation is such as ultimately to evolve into open affiliation. ${ }^{56}$ It is probable that one of the large rank and file unions would absorb any of the independent foremen's unions, if it were to its interest to do so, ${ }^{57}$ e.g., to prevent a rival union from taking over..$^{58}$ If the

52 National Labor Relations Act \& I, 49 Stat. 449 (1935), 29 U.S.C.A. § I5I (I942).

${ }^{33}$ Matter of Packard Motor Car Co., 64 N.L.R.B. No. 204, I7 Lab. Rel. Rep. 506, 507 (I945).

${ }^{54}$ Matter of Packard Motor Car Co., 6I N.L.R.B. 4 (r945).

ss Ibid., at 30 . See Slichter Report, op. cit. supra, note I, at 29.

${ }^{56}$ For example, the affiliation of the Mine Official's Union with the UMW, note 13, supra; the affiliation of the plant guard unions with the CIO, Matter of Chrysler Corp., 44 N.I.R.B. 881 (1942); Matter of Dravo Corp., 52 N.L.R.B. 322 (1943).

57 "The efforts of independent organizations of foremen to retain their independence of rank and file organizations may or may not succeed. The rank and file may insist upon absorbing or controlling organizations of foremen in order to protect themselves against loss of employment through strikes of foremen or in order to increase the bargaining power of the rank and file unions. A union of rank and file employees could threaten the independence of a foremen's organization by offering to take the jobs of striking foremen. The outcome would depend in part upon the policy followed by employers." Slichter Report, op. cit. supra, note I, at I68.

${ }^{8}$ Note 24 , supra. To date, the CrO has disavowed any designs on supervisory employees despite some evidence to the contrary. See Slichter Report, op. cit. supra, note r, at 28 , 
Board had not accepted affiliation it would have found itself hopelessly involved in drawing fictional distinctions so as to preserve the illusion of independence, or, as Member Reilly indicated in his dissent in the first Packard case, involved in a hopeless policing job.

In the Jones \& Laughlin case there is a strong implication that the Board has discarded Ex-chairman Millis' limitation on affiliation, namely, that the supervisory employees had to be in "autonomous" locals in order to be certified, except in those industries having a history of mixed locals antedating the Wagner Act. ${ }^{59}$ In the light of the facts of this case showing complete domination of the UCTSE by the UMW even to the extent that the supervisory employees take the UMW oath and the UCTSE's officers are appointed by the UMW, ${ }^{60}$ the failure of the Board to discuss the question of autonomy in an otherwise voluminous opinion seems significant. There would be good policy reasons in limiting certification to autonomous locals of supervisory employees with a close identity of interests, which could develop and articulate the group policy in the union meeting hall as well as at the bargaining table and not be subject to domination, as individuals, by the production workers. ${ }^{6 x}$ However, it is questionable whether autonomy could be enforced without the Board's becoming in-

and the evidence of CIO support to the FAA presented in both Packard cases; see also, the very noncommittal testimony of Lee Pressman, general counsel, CIO, on this point in the Hearings on the Smith Bill, op. cit. supra, note 12, at 299.

59 “. . . . I would be inclined to concur in the dismissal of the petitions in this particular case if the decision to do so were predicated upon the petitioning union's failure to make proper provision for the organizational autonomy of the supervisors whom it seeks to represent." Matter of Maryland Drydock Co., 49 N.I.R.B. 733, 744 (1943); Matter of Rochester \& Pittsburgh Coal Co., 56 N.L.R.B. I760, 1765 (1944); Matter of Cramp Shipbuilding Co., 52 N.L.R.B. 309, 312 (1943).

${ }^{60}$ Matter of Jones \& Laughlin Steel Corp., 66 N.L.R.B. No. 5I (r946) (page I8 of memorandum of decision).

6x "The Panel regards this intention of the Foremen's Association [to remain independent] as important because the Panel does not believe that it is appropriate for supervisors, who are responsible for discipline, assignment of work, rate adjustments and promotions, who represent the employers in handling the grievances of rank and file workers.... to be subject to discipline by a union which is controlled directly or indirectly by the men whom they supervise." Slichter Report, op. cit. supra, note I, at I68.

".... there have been many instances in which foremen-union members, by virtue of their position as management representatives, have been able to exert minority control over unions composed of both supervisors and production workers; and other instances in which unions of production workers have organized and 'taken over' foremen to such an extent that the foremen cease to function as management representatives. Examples of the former are found among railway maintenance of way workers and East Coast longshoremen; examples of the latter, in the printing and building trades." Northrup, op. cit. supra, note 9, at I94.

Member Reilly has consistently expressed his fears that if affiliation is sanctioned, the supervisory employees might exercise undue influence over the rank and file union activities and their conduct would then be imputed to the employer, making him guilty of an unfair labor practice. These fears do not seem valid where the large international unions are concerned; and if this sort of thing does occur, the Board should be able to determine without too much difficulty whether the employer is involved. See Matter of Scullin Steel Co., 65 N.L.R.B. No. 219 , I7 Lab. Rel. Rep. 930 (1946). 
volved in difficulties similar to those which would have arisen if it had attempted to bar any form of affiliation. In the final analysis, control of the supervisors by the rank and file may be exercised in many indirect and informal ways, and all that the Board can effectively insist upon is that separate contracts be negotiated for the supervisory employees and that they be set up in separate locals. ${ }^{62}$

The primary safeguards against complete domination lie in the terms of the contracts that management negotiates with the unions. ${ }^{63}$ Indicative of this is the fact that, although the Board has sanctioned affiliation, it may have offered management a means of avoiding the problem if, as seems likely, the Board follows the course it took in dealing with the plant-guards cases. The plant guards, if they were in a separate local, had been permitted by the Board to affiliate with, and designate as their bargaining agent, the parent rank and file union ${ }^{64}$ Then, in an unexpected decision, Chairman Herzog sided with Member Reilly to overthrow the established line of decisions, ${ }^{65}$ which had held that the production unions could not bargain away the right of the plant guards, granted by the Wagner Act, to designate the production union as its bargaining agent. The Board now holds that where the industrial union has contracted with management not to organize or take in the plant guards, the plant-guard unit cannot designate the industrial unit as its bargaining agent. ${ }^{66}$ If this decision is

${ }_{62}$ The Board is utilizing another safety factor in cases where there are common backgrounds, interests, and problems among different levels of supervisory employees, but where the top supervisors have power to affect changes in the status of the foremen. While the Board will not act to put them in separate units, it will require that the top supervisors vote separately and decide whether or not they wish to be included in the same bargaining unit as the others. Matter of Kelsey-Hayes Wheel Co., 66 N.L.R.B. No. 76, 17 Lab. Rel. Rep. 975 ( 1946 ); Matter of Midland Steel Products Co., 65 N.L.R.B. No. I77, I7 Lab. Rel. Rep. 858 (1946). Member Houston dissented in these cases, objecting to the separate election requirement.

${ }^{6}{ }_{3}$ Thus the contract recently negotiated between the Kaiser-Frazer Corporation and the UAW provides that should the N.I.R.B. place supervisors in a unit for representation purposes, and if that unit selects the UAW to represent them, then these supervisory employees will be grouped in a separate local and the UAW will not request that the present contract be extended to them; I 7 Lab. Rel. Rep. 846 (I946). The Ford and Chrysler Corporations, in their new contracts with the UAW, following a more conservative pattern, provide that the UAW will not take in or represent supervisory employees in collective bargaining procedures; see note 6, supra. Ford has had a separate contract with the Foremen's Association of America since November, I942.

${ }_{4}$ Matter of Chrysler Corp., 44 N.L.R.B. 88I (1942); Matter of Dravo Corp, 52 N.L.R.B. 322 (1943).

${ }_{65}$ Matter of Federal Motor Truck Co., 54 N.L.R.B. 984 (1944); Matter of Briggs Indiana Corp., 49 N.L.R.B. 920 (1943); Matter of Briggs Mfg. Co., 49 N.L.R.B. 57 (1943); Matter of Ford Motor Co., 47 N.L.R.B. 946 (1943); Matter of Packard Motor Car Co., 47 N.L.R.B. 932 (1943). Since the production union cannot be required to represent the plant guards and inasmuch as ". . . . the agreement is not in the nature of a yellow-dog contract, extracted from a helpless individual employee, but was made as part of a collective bargaining between presumptive equals," the rationale of these cases in terms of the bargaining away of statutory rights seems highly questionable. Matter of Briggs Indiana Corp., 63 N.L.R.B. I 270 , 17 Lab. Rel. Rep. 167 (1945).

${ }^{66}$ Matter of Bricgs Indiana Corp., 63 N.L.R.B. I270 (I945). Member Houston dissented. 
applied to supervisory employees, further affiliation of supervisory employees and rank and file unions may be forestalled for so long as management can get the rank and file union to contract not to organize or bargain for supervisory employees. ${ }^{67}$

The Board has still to decide how high up the managerial ladder it will certify employees' organizations as appropriate bargaining units. Theoretically, in a corporate organization, the stockholders are the "employers" while even high corporate officers fall into the category of "employees," as defined in the act. ${ }^{68}$ Implicit in the Board's certification decisions has been the application of a criterion in terms of "prerogatives of management," in particular, the policymaking function, and the individual has been included in the bargaining unit in so far as he has or has not certain of these prerogatives. ${ }^{69}$ Thus the Board in the first Packard case ${ }^{70}$ was careful to spell out the subordinate position of the supervisory employees involved. However, in Matter of L. A. Young Spring \& Wire Corp..$^{7 x}$ the majority indicated that this was not conclusive.

.... we do not believe that the application of the Act, to foremen can or arbitrarily should be made to depend upon the type of industry involved, whether mass production or non-mass production, or atpon the variation in the duties and responsibilities of foremen from company to company. ${ }^{72}$

Where, if at all, the Board will draw the line ${ }^{73}$ is not determinable, ${ }^{74}$ and it may, after all, be largely a hypothetical problem. Corporate officers, vested

${ }_{67}^{7}$ See note 63 , supra. In Matter of Jones \& Laughlin Steel Corp., 66 N.L.R.B. No. 5I, I7 Lab. Rel. Rep. 97I (I946), the company attempted to invoke the doctrine of the Briggs case. The Board, however, found that the UMW had never contracted with the coal operators not to organize supervisory employees. This conclusion is in accord with the dissenting opinion of Member Gregory of the Coal Supervisors panel, Coal Panel Report, op. cit. supra, note I3, at 14 .

o8 “' 'Where will unionization end?' he [C. E. Wilson, President of General Motors] asks, 'With the vice-presidents?' Wilson does not like to quote a spectacular figure in Detroit, Matthew Smith, Secretary of the Mechanics Educational Society of America, but the industry in general frequently refers to his remark that everybody but stockholders should belong to unions and that his own is prepared to take in Wilson." The Foreman Abdicates, 32 Fortune, No. 3 at $\times 50$, 152 (Sept., 1945).

${ }^{69}$ See Daykin, op. cit. supra, note II, at $318 . \quad{ }^{70} 6$ r N.L.R.B. 4 (I945).

${ }^{7} 65$ N.L.R.B. No. 59, 17 Lab. Rel. Rep. 687 (1946).

72 Ibid., at 687 (italics added); Matter of B. F. Goodrich Co., 65 N.L.R.B. No. 58, 77 Lab. Rel. Rep. 692 (1946); Matter of Jones \& Laughlin Steel Corp., 66 N.L.R.B. No. 5 I, 17 Lab. Rel. Rep. 97 (I946); Matter of Federal-Mogul Corp., 66 N.L.R.B. No. 70, 77 Lab. Rel. Rep. 975 (1946); Matter of Celotex Corp., 66 N.L.R.B. No. -, I7 Lab. Rel. Rep. 984 (1946), holding that foremen are employees and ".... the nature of their duties and responsibilities is relevant only in so far as it relates to the proper grouping of the foremen for collective bargaining purposes."

73 The United States Supreme Court has held that determining who is an employee under the act "belongs to the usual administrative routine" of the Board. N.L.R.B. v. Hearst Publications, Inc., 322 U.S. III, r30 (r944).

74 The Foremen's Association of America, by its constitution, admits to membership any foreman of "good moral character" except the foremen "... . who is an employer of labor, 
with all or most of the prerogatives of management, are not likely to feel the need for collective-bargaining procedures to further their ends in the predictable future.

Management and labor have been hard put in having to base their line of conduct upon the vagaries of a fluctuating administrative body applying an act which makes no explicit provision for the class of persons involved. Since the Wagner Act was passed in 1936, changing conditions, unforeseen by the lawmakers, have revealed certain more or less serious flaws and omissions in the act. ${ }^{75}$ Among these is the omission of an expression of legislative intent as to supervisory employees. While the Board's current position with respect to supervisory employees is sound and will most probably be upheld by the Supreme Court, ${ }^{76}$ the decision which the Board has been forced to make is one of basic policy and should be made not by an administrative agency but by Congress. ${ }^{77}$ However, it is extremely doubtful whether Congress will furnish the Board with a new set of rules in labor-management relations. As long as the balance of power in Congress remains as precarious as it currently is, it is to be expected that Congress will, by default, allow the National Labor Relations Board and the courts to continue to establish the rules as they proceed from case to case. Despite the obvious inadequacies of this course, it is preferable to any of the legislation dealing with the problem that has been up for Congressional consideration..$^{8}$ Furthermore, no hard and fast rules can be laid down that would obviate the need for administrative discretion in particular cases, unless legislation is adopted categorically excluding supervisory employees from

or individual in a position to act as negotiator in the interest of employer policy." Northrup, op. cit. supra, note 9, at 19o. The New York State Labor Relations Board, applying a "prerogatives of management" test, has held that motion-picture theatre managers may form a unit appropriate for collective bargaining. Matter of RKO Service Corp., 7 N.Y.S.L.R.B. 175 (1944).

75 The most notable flaw in the act is the failure to provide for the numerous problems incident to the organization of the CIO and the ensuing dual unionism.

${ }^{76}$ There is language in the opinions of the Supreme Court indicating that if and when the Packard and Jones \& Laughlin cases reach the Court (see note 7, supra) the Board's findings may be treated as conclusive. See N.L.R.B. v. Hearst Publications, Inc., 322 U.S. III, I30 (I944); N.L.R.B. v. Nevada Consolidated Copper Corp., 316 U.S. 105, 106 (1942). In any event, the Court, like the Board, can only work within the framework of the present act.

77 Chairman Herzog, appearing before the Senate Education and Labor Committee in hearings on the Case Labor Bill on February 28, 1946, testified that "as to the NLRB's views on the proposed definition of 'employee' [note 5, supra] to exclude supervisory employees from the coverage of the Wagner Act .... the Board unanimously agreed that this question was a broad one of national policy on which it aught not to advise the Congress." I7 Lab. Rel. Rep. 879,880 (1946).

${ }^{8}$ The Case Bill would have excluded foremen from the protection of the Wagner Act; the Smith Bill would have forbidden supervisory employees from joining a union under penalty of being drafted. 
joining unions. ${ }^{79}$ The passing of such legislation, if constitutional, would offer no real solution to the management-foreman problem and would only lead to the sort of strife that the Wagner Act was designed to avoid. ${ }^{80}$

\section{THE SHERMAN ACT AND THE MOTION PICTURE INDUSTRY}

The application of the Sherman Act to the motion picture industry has been long continued and erratic. This uncertainty as to the position of the industry within the framework of the antitrust laws has been most noticeable during the past eight years. In 1938 the Government brought a suit against the eight major producer-distributors the main purpose of which was to divest five of the defendants of their exhibition houses. ${ }^{x}$ In 1940 the Government acquiesced in a consent decree under which the industry was given three years in which to govern itself. ${ }^{2}$ Currently the Government is once again seeking to divest the socalled majors of their exhibition interest. ${ }^{3}$ The merit of the consent decree is basic to the present dispute. The Government premises its request for divestiture upon the inadequacy of the decree. The defendants insist that the decree was a satisfactory solution to the complex of problems which resulted from the

79 See Northrup, Unionization of Foremen, 21 Harv. Bus. Rev. 496, 504 (r943).

${ }^{80}$ Chairman Herzog, in his testimony on the Case Bill, op. cit. supra, note 77 , at 880 , called attention to the following possible courses Congress might take:

"One would be to leave the Wagner Act in its present form, relying upon the Board and the courts to determine which policy is most consistent with the Act. A second would be to protect supervisory employees against discrimination but not to require employers to bargain with the union they might select. A third would be to require employers to bargain with an independent, unaffiliated union of supervisory employees, but to remove the obligation where foremen select a union affiliated with an organization chosen by rank and file employees. A fourth alternative would be to adopt the bill as it passed the House. A fifth would be to change the definition of supervisory employee so as to afford Wagner Act protection to minor supervisory employees only."

I United States v. Paramount Pictures, Civil Action No. 87-273 (D.C. N.Y., 1938). Of the eight defendants, Twentieth-Century Fox, Loew's, Paramount Pictures, Radio-KeithOrpheum, and Warner Brothers (the "Big Five") are engaged in both the production and distribution of motion pictures and also have extensive holdings in the exhibition end of the industry. The other defendants, known as the "Little Three," are Columbia Pictures, Universal Corporation, and United Artists Corporation. Columbia and Universal engage in the production and distribution of film but do not operate any theaters. United Artists distributes motion pictures. See Plaintiff's Trial Brief, filed September, $x 945$, United States v. Paramount Pictures, Civil Action No. 87-273 (D.C. N.Y., I938) (hereinafter referred to as Plaintiff's First Brief).

2 C.C.H. Trade Reg. Serv. (8th ed., x940) $\Upsilon_{25,558}$.

3 By section 2I of the consent decree, the Government agreed to refrain from divorcement proceedings for three years. At the expiration of this period negotiations for a new decree were commenced. Since the producer-exhibitors refused to agree to divestiture, which the Government regarded as essential, the case was again brought to trial. Plaintiff's First Brief 4 . 